\title{
The Farmington Plan and the Select List of Unlocated Research Books
}

Mr. Cook is associate in library service, School of Library Service, Columbia University.

$\mathrm{T}$

He Farmington Plan, its general purposes and operation, and its major advantages and disadvantages all seem sufficiently well known to permit omission of any general discussion as an introduction to this paper. The recent publication of Edwin E. Williams' excellent Farmington Plan Handbook ${ }^{1}$ puts a complete and authoritative body of information at the disposal of the reader interested in investigating the details of the Plan.

However, there is at present only a small amount of material which attempts to evaluate objectively the degree of success with which the Plan is operating. David and Hirsch $^{2}$ offered the first study, using Swiss publications in their investigation. Peiss undertook a more thorough study of the same area, and the Farmington Plan Office largely completed this work upon his death. ${ }^{3}$

It seems desirable to continue such studies of the success of the Farmington Plan acquisitions, and at first it was felt there might be merit in repeating, for a later period, the David and Hirsch study, in an

1 Williams, Edwin E. Farmington Plan Handbook. Bloomington, Ind., Association of Research Libraries, 1953. (Includes full bibliography of writings on the Plan.)

${ }_{2}$ David, Charles W. and Rudolf Hirsch, "Importations of Foreign Monographs Under the Early Influence of the Farmington Plan," COLLEGE AND RESEARCH LibRARIES, 9: I OI-05, April I 950.

${ }^{3}$ Farmington Plan Letter, no. 6, November 18, 1952, pp. $4 \cdot 5$. attempt to determine what, if any, changes had occurred. After careful consideration, and particularly in view of the Peiss study, this project was abandoned as of relatively little significance, since it was probable that the results would evaluate, not the success of the Farmington Plan itself, but the competency of the Swiss dealer selected as agent for the Plan. Consequently, a new approach was sought.

The Select List of Unlocated Research Books is a publication of the Union Cata$\log$ Division of the Library of Congress representing "a selection of the books needed by research workers in the United States... but which were not found in the National Union Catalog nor located in the 64 leading reference libraries that check the Union Catalog Division's Weekly List of Unlocated Research Books." 4 Since the Select List purports to contain books "needed by research workers in the United States," and the Farmington Plan attempts to secure material which "might reasonably be expected to interest a research worker in the United States," ${ }^{5}$ it seemed reasonable to check one against the other as a measure of relative success. In short, if certain titles actually are desired and requested, are the carefully calculated "guesses" of the Farmington Plan meeting these desires and requests?

This general question has its corollaries.

\footnotetext{
${ }^{4}$ United States. Library of Congress. Union Catalog Division. Select List of Unlocated Research Books. No. I7, 1953, p. iii.

s Williams, op. cit., p. 3.
} 
What books are sought which have been published since the beginning of the Farmington Plan? Which of these titles were not located in the United States? Should the Farmington Plan have supplied these books, and if not, why? Is there any area, in country, subject or form, which the Farmington Plan is not covering? If omissions are found, are these intentional? Is the omission a serious one? What may be needed to remedy any defect found?

Certain limitations exist in testing the Farmington Plan by means of the Select List. There is no possible way to determine the number or kind of books which have been sought by some research worker, and which have been supplied by his own or another library because the Farmington Plan exists, and which otherwise might not have been available. As currency and commercial regulations have eased gradually since the Plan began, libraries have found it easier to obtain materials abroad, and so whether or not they are participants, they are less dependent on the Plan for securing needed titles. The bibliographical accuracy of the entries in the Select List is open to some question, and this restricts its value as a testing device for the purposes of this inquiry. The kind of material actually sought is occasionally of dubious importance. However, since the Farmington Plan includes marginal material, this has not been considered a serious drawback to using the Select List, although in some cases it would not be surprising to find that a Farmington agent had not even considered including some material which has been sought.

Use of the Select List might lead to an assumption that it indicates accurately what is needed by research workers. Unfortunately, this is not wholly true. It is, first, only a selection of what has been sought; and, second, it is obvious that a library does not request for its clientele all desired material which it does not possess. A research worker may find a publication useful if it is at a certain place at a given time; if not, no further search for it may be made. A library lacking and needing a certain book may place its own order for it, without attempting to secure it from another library. Subsequently, the book would be available, whether or not the Farmington Plan were to obtain it.

Eighty-seven libraries were considered in the inquiry, together with three regional centers which by their nature are not members of the Farmington Plan, but which check the Weekly List from which the Select List is compiled. Of the libraries which participate in the Farmington Plan and the search for research titles, less than half ( 37 or $42.5 \%$ ) are included in both. This group forms a kind of core, in which it will be assumed that checking and Farmington Plan receipts can be compared accurately. An additional 25 libraries $(28.7 \%)$ are members of the Plan, but do not check the Weekly List. Since participants in the Plan are under an obligation to report Farmington receipts to the Union Catalog within one month of their arrival, it might be assumed that this group could be added to the original "core." It is doubtful that this is true, for if the experience in one library is typical, a delay of from six to eighteen months may occur before the title is reported to Washington. An identical $28.7 \%$ constitutes the final group, which checks the Weekly List but which does not belong to the Plan. This means that resources over and above those of the Plan have been drawn upon in the search for titles; certain non-members may be supplying wanted materials which may not have been obtained through the cooperative project.

The contents of the four issues of the 
TABLE I

Analysis of Content of Four Issues of the Select List

\begin{tabular}{lrrrr}
\hline Select List Number & I 4 & I 5 & I6 & I7 \\
Books Sought In & I949 & I950 & I 95 I & I952 \\
Total Number of Titles & I64 I & I 437 & I 208 & 1697 \\
$\begin{array}{l}\text { Number of I948-5I } \\
\quad \text { Titles }\end{array}$ & 43 & 56 & 53 & 100 \\
$\begin{array}{l}\text { Percentage of I948-5I } \\
\text { Titles }\end{array}$ & 2.6 & 3.8 & 4.4 & 5.8 \\
\hline
\end{tabular}

Select List which were examined are analyzed briefly in Table I. The gradually increasing percentage of titles published since 1948 is normal, and probably this will not decline for some time.

The percentages of annual increase in the number and percentage of 1948-5 I titles in the Select Lists examined are shown in Table II. Without a Farmington Plan, the two would be expected to rise or fall at roughly the same rates. With the Plan, it is to be hoped that the annual increase in the percentage of titles published since 1948 will be slower than the increase in their actual number. This has occurred in the issue of the Select List covering material sought in I952. If this continues, it would seem to be a rough indication that the Plan is succeeding.

In Table III, Select List no. 17, covering

TABLE II

Percentage of Annual Increase in 1948+ Titles

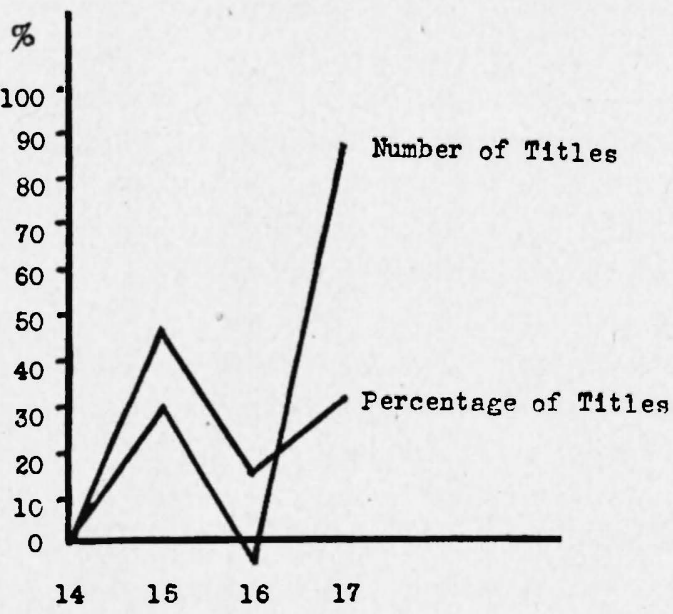

TABLE III

Materials Excluded from the Farmington Plan -From Select List No. I7-

(Adapted from Williams, op. cit., p. 68)

Almanacs

Annuals

Bibles

Books costing more than $\$ 25$

Books of interest chiefly for format or typography

Calendars

Dissertations and theses for academic degrees

Official government and United Nations publications

Extracts, reprints, separates or "offprints" from books or periodicals

Juvenile literature

Maps (i.e. sheet maps)

Medicine

Music scores (i.e. sheet music)

Newspapers

Periodicals

Series: (a) if numbered and issued by societies or by academic institutions; (b) if numbered, that began before the Plan was extended to the country of their publication

Textbooks of lower than college level

Theology

Translations from a modern language

Country not included

Incorrect imprint date (i.e. not actually I $948-5$ I)

Insufficient information

TOTAL

$\begin{array}{lll}2 & 4 & 6 \\ \text { I } & & \text { I } \\ & & \\ & 2 & 2\end{array}$

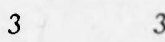

I 45

I $\quad$ I 2

6I 6 I

2 I 3

\begin{tabular}{lll} 
& & 17 \\
\hline 71 & 12 & 100
\end{tabular}

* I: Established.

2: Probable.

3: Total.

material sought in 1952, has been partially analyzed. An even roo titles were found which had been published in 1948 or later and which had not been located in the United States. These have been checked in reasonable detail in bibliographies in an effort to determine whether or not they should have been obtained through the Farmington Plan. With the information thus obtained, the titles have been classified according to the categories of materials intentionally excluded from the Plan, with three additional categories to provide for 
the remainder. For $7 \mathrm{I}$ books, it was possible to establish the fact of intentional exclusion. For 12 more, probable reasons for exclusion were found, leaving only I 7 titles which insufficient information made it impossible to classify. Some titles could be excluded for more than one reason, but since exclusion of the country of publication was a factor in each instance, this has been the reason indicated in the table.

Exclusion of the country of origin at the time of publication accounted for the failure to obtain $6 \mathrm{r}$ titles. These countries are given in Table IV. $57.3 \%$ of the titles come from countries which subsequently were included in the Farmington Plan, and of the remaining titles, only three came from countries which might reasonably be included in the future: the Argentine Republic, Trieste, and Uruguay. The United States itself is an automatic exclusion; and after study, it has been decided by the members of the Plan not to include Great

\section{TABLE IV}

Origin of Publications Excluded Because of Country of Publication

\begin{tabular}{lc}
\hline \multicolumn{1}{c}{ Country } & $\begin{array}{c}\text { Number } \\
\text { of Titles }\end{array}$ \\
A. Countries Subsequently Included & 35 \\
Algeria & I \\
Austria & 2 \\
Belgium & I \\
Burma & I \\
Egypt & I \\
Germany & I I \\
Greece & 3 \\
India & 4 \\
Israel & I \\
Italy & 4 \\
Netherlands & I \\
Spain & 5 \\
\hline
\end{tabular}

B. Countries Not Yet Included Argentine Republic

Goa

Great Britain

Poland

Trieste

U.S.S.R.

United States

Uruguay
Britain. Poland and the Soviet Union are excluded automatically until such time as it may be possible to resume normal book trade with these countries. Goa may be considered a "freak" for it is highly unlikely that this country would appear on other lists, and it is also unlikely that it would be important to include it in Farmington countries.

No category other than country of publication accounted for a sufficient number of unobtained titles to warrant serious concern.

However, I7 titles remain as possible Farmington Plan omissions. Three may be removed as titles which an agent might be expected to ignore (a guide to a small church, a catalog of an exhibition of minor sculpture, and a single volume of a continuation). Of these 14 titles, it seems not unreasonable to assume that with further information, part would be shown to be intentional Farmington exclusions.

Let us say that ro titles remain as unexplained Farmington Plan omissions. If this is read as $10 \%$ of the research material which cannot be found in the United States in a given year, the figure, while not frightening, probably would give rise to some concerned study. If, however, the figure is read as only ro titles not located, and which should have been here, then the number is ridiculously small. When the actual titles are examined, it is difficult to imagine that their unavailability could cause more than a slight inconvenience to a particular research worker-an annoyance which can by no stretch of the imagination be translated into a problem of sufficient size to demand much further attention from librarians. From the limitations of the Select List which have been mentioned, it is apparent that neither of these answers is a wholly accurate one, but it would seem

(Continued on page 3I2) 
in a minority. Without more exact figures as to book loss, it is difficult to judge whether patrons coming out of the stacks should be checked. Two open stack libraries that reported exact data have a low book loss. One may speculate what the picture would be if every library kept exact figures on book loss as compared to total volumes. A two per cent loss in a college library of 50,000 volumes means a loss of I,ooo books. When replacement costs are considered, a small percentage loss could be quite serious.

There seems to be no clear indication of an increase or decrease of circulation with open stacks.

A most important fact brought out by the questionnaire is the absence of sufficient data on which to base definite conclusions of the merits of open or closed stacks.

Results of the questionnaire indicate that there is divided opinion on the number of personnel needed by an open stack library. Local conditions may directly affect the size of staff.

Colleges with open stack libraries average 609 students. Colleges with closed stack libraries average 653 students. Yet the libraries with open stacks average approximately one more full time person, 3.88 as against 3.01. Also 38 out of 52 open stack libraries still give page service. It would seem that page service could be dispensed with when the stacks are opened to patrons, but this does not seem to be true in the majority of the open stack libraries. A library that changed to open stacks recently reported that it found that there had to be a shift in duties but no decrease in staff.

From the answers given to the questionnaire, there is a trend toward unrestricted or freer use of periodicals.

Another interesting point brought out by the questionnaire is that 23 out of 69 libraries have reserve books on open shelves.

The significant fact brought out by this survey of the libraries of colleges with less than I,OOO students is that regardless of whether a library has open or closed stacks, librarians are generally thinking in terms of a freer use of materials. This trend seems to warrant the prediction that the practice of open stacks will be extended in accordance with such thinking.

\section{The Farmington Plan \\ (Continued from page 284)}

that there is foundation for the second interpretation.

Should the Farmington Plan consider removing any of its intentional exclusions? Periodicals did not appear at all in this study, and so no suggestion can be offered. Dissertations and textbooks did appear, but to no considerable extent. These categories are under discussion for inclusion, and it seems probable that some selection of these will be obtained in the future, if a satisfactory basis for selection can be agreed upon. Government documents are remarkable for their virtual absence, but it would seem that their importance and use in this country might be the subject of further inquiry.

From this brief study of the success of the Farmington Plan acquisition policy, it seems that compliments are due its organizers for so competently covering the field in such a short span of time. However, this study indicates the desirability of anothermuch more difficult to conduct-into the actual source of the needed research books which are supplied to research workers. In short, the opposite of the present inquiry would be valuable as a positive approach. 